\section{Hemmelighetene innen alternativ behandling}

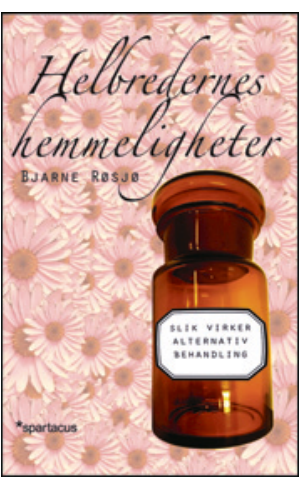

Bjarne Røsjø

Helbredernes hemmeligheter

Slik virker alternativ behandling. $224 \mathrm{~s}$.

Oslo: Spartacus forlag, 2012. Pris NOK 299

ISBN 978-82-430-0678-2

Denne boken er skrevet av forskningsjournalisten Bjarne Røsjø, som for tiden er medierådgiver i Klima- og forurensningsdirektoratet. Utgivelsen er et nytt bidrag i den pågående offentlige debatten omkring alternativ behandling. Søkelyset er rettet mot å prøve å forklare kunnskapsgapet mellom kritikernes «tendens til å avfeie alternativ behandling som tull og tøys og placeboeffekter», og alternative behandlere som hevder at de «forvalter en helhetlig kunnskap som legevitenskapen ignorerer» (sitat fra omslaget).

Boken leveres som hardback uten tabeller, figurer og stikkordregister. Språket er ikke vanskelig tilgjengelig, selv for lesere utenfor den medisinske profesjonen. Målgruppen er ikke oppgitt, men på omslaget står det: «Alle som er interessert i alternativ behandling, har mulighet til å få ny kunnskap hvis de leser denne boka.» Hensikten er heller ikke oppgitt, men videre på omslaget står det at «boka lanserer en tredje og mer balansert fortelling om Det alternative Norge».

Temaene er presentert i 14 kapitler, supplert med noter og litteraturhenvisninger. I første kapittel gir forfatteren en kort oversikt over de temaene han tar opp. Disse vil alle bidra til å støtte opp under forfatterens hovedbudskap, som han lanserer allerede på side 8: «Resultatene av alternativ behandling kan ... i stor grad forklares ved hjelp av kjente naturvitenskapelige, skolemedisinske og psykologiske prinsipper.» Resten av boken utdyper dette fra ulike vinklinger som i sum skal avsløre helbredernes «hemmeligheter». Noen av temaene er velkjente: skolemedisinens røtter i naturen, medisinplanter, styrken til placeboeffekten og kroppens selvhelbredende krefter. Sammenhengen mellom mentale forhold og helse hevder han kan forklare «mye av det som foregår når syke mennesker oppsøker Snåsa-mannen eller andre dyktige alternative behandlere». De velkjente temaene bidrar ikke med vesentlig ny informasjon i debatten. Forfatteren tar imidlertid inn noen momenter som ikke tidligere har vært så fremtredende i forklaringen av effekt innen alternativ behandling.

Et av disse er speilnevronfenomenet. Speilnevronsystemet ble først identifisert på 1990-tallet av en italiensk forskergruppe i Parma. Røsjø hevder at alternative behandlere muligens har et spesielt godt utviklet speilnevronsystem. Det gjør at de i stor grad korrekt kan forstå og tolke pasientens ansiktsuttrykk og annet kroppsspråk. De oppfattes dermed som usedvanlig forståelsesfulle og empatiske, og pasienten vil kunne hevde at «ingen hadde skjønt hva som feilte meg, men denne behandleren så hva som var i veien til og med før jeg hadde åpnet munnen».

Det andre momentet er narrativer: Forfatteren skriver at «en narrativ fortelling, eller kort og godt et narrativ, er en metafor for at vi mennesker opplever og erfarer våre liv gjennom de fortellingene vi lager». Selv om forfatteren ikke fastslår det i klartekst, må man forstå ham slik at han mener at narrativ omredigering er en faktor som kan forklare pasientenes fornøydhet med alternative behandlere. Dette standpunktet er helt i tråd med de danske antropologene Johannessen og Ostenfeld-Rosentahl, som i en nylig utgitt bok (1) skriver at «en narrativ er af mange medicinske antropologer blevet fremhævet som væsentlige i processen med at genskabe en meningsfyldt orden i det brud på mening, som en lidelse medfører, og dermed som væsentlige for at genskabe en forståelig verden for den enkelte». Alternative behandlere er angivelig bedre enn leger i å hjelpe pasienter med å skape sin meningsfulle fortelling.

Har så forfatteren evnet å beskrive en «tredje og mer balansert fortelling om Det alternative Norge»? Min vurdering av dette er både ja og nei. De to nyere momentene han introduserer, sammenholdt med resten, gjør at man kan skimte hans helhetlige teori om hvorfor alternativ behandling både appellerer og virker. Selv om han selv ikke formulerer den klart, er min oppsummering slik: Alternative behandlere tar bevisst eller ubevisst i bruk kjent psykologisk og antropologisk kunnskap i sitt møte med pasienter. De bruker denne kunnskapen på en terapeutisk gunstig måte, og størstedelen av effekten som pasienter beskriver, må tilskrives dette. De terapispesifikke «teknikkene», som homeopatiske midler, kostholdstilskudd, akupunkturnåler og «varme hender» har liten eller ingen egeneffekt.

Samtlige legekolleger jeg har snakket med om mulig effekt av alternativ behandling, fremhever at det dreier seg om «placeboeffekt» innen en romslig definisjon av hva placeboeffekt er. Nå er det på tide å studere disse angivelige effektene nærmere, enten ved å studere hver komponent for seg, eller ved en større satsing på «comparative effectiveness»-forskning. Hvis denne teksten kan bidra til en klarere forståelse for nødvendigheten av slik klinisk forskning, er det tatt et viktig steg fremover. Kanskje resultatene, hvis positive, ville være av størst nytte for leger.

\section{Vinjar Fønnebø}

Nasjonalt forskningssenter innen komplementær og alternativ medisin Tromsø

\footnotetext{
Litteratur

1. Johannessen H, Ostenfeld-Rosenthal A. Alternativ behandling. Praksis og fakta. København: Munksgaard, 2012
} 